\title{
Mental Health and Legal Representation for Asylum Seekers in the "Legacy Caseload"
}

\author{
Mary Anne Kenny \\ Murdoch University \\ Nicholas Procter \\ University of South Australia \\ Carol Grech \\ University of South Australia
}

\begin{abstract}
This article examines the legal challenges asylum seekers arriving by boat to Australia experience when seeking assistance with their claims and its impact on their mental health. The authors outline the experiences of asylum seekers in the "legacy caseload" group who have been waiting up to four years to have their protection claims assessed. The complex interplay between legal assistance to support refugee claims and the way those making claims inevitably struggle to understand, engage and participate in the process is analysed. It is argued that provision of legal assistance for this group will be essential to ensuring that the refugee status determination process is fair and allows asylum seekers to understand and participate more fully in the process. Recent changes to the assessment of claims combined with a reduction in funding for legal assistance create significant hurdles and combine to compound existing stress and emotional trauma leading to detrimental outcomes on the mental health of asylum seekers.
\end{abstract}

\section{Introduction}

The following is an account from an immigration lawyer describing her interaction with an asylum seeker during a legal advice session at a community legal centre in Queensland, Australia.

He pushed an envelope across the table that contained a letter. His weathered face apologised 'no English - help?'.... He can’t write in his own language (let alone read or write English) - the legacy of his experience of war and persecution in his home country.

Mary Anne Kenny, School of Law, Murdoch University; Nicholas Procter, School of Nursing and Midwifery, University of South Australia; Carol Grech, School of Nursing and Midwifery, University of South Australia. Corresponding author: m.kenny@murdoch.edu.au ISSN: 1837-5391; https://epress.lib.uts.edu.au/journals/index.php/mcs CCS Journal is published under the auspices of UTSePress, Sydney, Australia (C) 2016 Mary Anne Kenny, Nicholas Procter, Carol Grech. This is an Open Access article distributed under the terms of the Creative Commons Attribution 4.0 Unported (CC BY 4.0) License (https://creativecommons.org/licenses/by/4.0/), allowing third parties to copy and redistribute the material in any medium or format and to remix, transform, and build upon the material for any purpose, even commercially, provided the original work is properly cited and states its license. 
He can't understand what this 6 page, densely written, highly official letter wants of him. We are lucky that the organisation I volunteer as an immigration lawyer with has access to interpreters.

After introductions, this man tells me that he does not understand what he has to do, but he can see that he has little time to do it in - in fact just 28 days. He says he is so worried about not gaining protection from Australia that he cannot sleep. Then he breaks down.

For the next 10 minutes, between racking sobs that he has no control over, he tells me that he has failed his wife and children. They are in danger and he cannot help them. He says he feels useless, like a child. In his culture, breaking down like that in front of a woman is not 'done'.

I ask him when he arrived at Christmas Island. He can't remember. Finally he says it was in 2012. He cannot recall the month or day. He has no hope of answering the 110 questions on the temporary protection application form (many of which have up to 14 sub-questions) without assistance. Completing a protection application takes many hours to get down the bare basics, especially when mental ill-health is impacting as it now is for so many of these asylum seekers. ${ }^{1}$

This interaction symbolises the intersection between complex trauma, language barriers and cross-cultural differences that inevitably impact upon asylum seekers' ability to recount past experiences. At a deeper level the interaction illustrates the difficulties of an asylum seeker understanding and engaging in a complex legal process that will determine their future. The lawyer is providing assistance pro bono and recounts the difficulty of doing this when there are no funded legal services to assist the asylum seeker.

This paper examines the cataclysm facing asylum seekers who arrived in Australia by boat between August 2012 - December 2013 that have come to be known as the "legacy caseload". This group have been the subject of continuous pressure due to a number of punitive policy changes that include: waiting for several years to have their refugee claims determined; legislative changes which mean their cases are now subject to accelerated processing; removal of access to permanent residence; and, a drastic reduction in funding for legal assistance.

This article explores the processes and challenges attendant upon these asylum seekers, many of whom are known to have worsening mental distress, to obtain legal assistance for their

\footnotetext{
${ }^{1}$ A description of a client interview reproduced with the permission of the author.
} 
claims. The authors set about explaining the complex interplay between legal assistance to support refugee claims and the way those making claims inevitably struggle to understand, engage and participate in the process and the profound impact this has on their mental health.

\section{Background - the vulnerability of the legacy caseload}

Globally we are witnessing the largest forced movement of people since the Second World War with an estimated 60 million people forcibly displaced due to conflict or insecurity (UNHCR 2015). In 2012-2013, Australia had a rapid increase in the number of asylum seekers attempting to reach Australia by boat with over 25,000 people arriving in one year (Phillips 2014). These asylum seekers arrived in Australia expecting to present their claims for protection. They have become known as the "legacy caseload".

It is well documented that after arrival in a new country asylum seekers deal with a raft of issues such as bereavement, mental health problems, cultural and language barriers (Sinnerbink et al 1997, Procter 2005). Asylum seekers in the legacy caseload, however, are experiencing an additional and unique series of policy and legislative shifts in their status resolution "journey" in Australia. This "journey” includes detention; release into the community with limited support and on-going uncertainty around their visa status. All of which ultimately culminates to imbue a detrimental effect upon their mental health.

The arrival of a large number of people in Australia by boat in 2011-2012 led the Federal Gillard Labor government to seek advice from a panel of experts on policy options available as to 'how best to prevent asylum seekers risking their lives by travelling to Australia by boat' (Prime Minister of Australia 2012). This panel recommended the reinstatement of offshore processing for boat arrivals and the application of a "no advantage" principle to all boat arrivals. The policy of "no advantage” was to ensure 'that those who choose irregular and dangerous maritime voyages to Australia in order to seek asylum are not advantaged over those who seek asylum through regular migration pathways and established international arrangements' (Australian Government 2012, p. 20). The “no advantage” policy was applied to asylum seekers who had arrived by boat after 13 August 2012. This meant that the protection claims of asylum seekers who came to Australia by boat after this date would not be processed any faster than if they had remained in transit countries such as Indonesia or Malaysia, or in their neighbouring countries. 
Asylum seekers who arrived by boat during 2012-13 were detained upon arrival in remote detention centres in Christmas Island or Darwin. There is clear international evidence to indicate a relationship between mental deterioration and increasing time in held detention. A global systemic review of research into the impact of detention in Australia, the United Kingdom (UK) and the United States of America (USA) by Robjant and colleagues, confirmed that immigration detainees evince high levels of mental health problems and suicidal behaviour which worsen over time in detention (Robjant el al 2009).

Boats continued to arrive and pressure on the capacities of the onshore detention network and regional processing centres to absorb the new arrivals increased. After time held in detention, ranging from weeks or several months, asylum seekers began to be released from detention into the community on bridging visas (BV) without work rights while they waited an outcome on their asylum claims. Families and certain vulnerable individuals were released into Community Detention with no right to work. Simultaneously, several hundred men, women and children were sent overseas and detained in regional processing centres in Nauru or Manus Island in Papua New Guinea in order to have their refugee claims processed only to be returned and released into the Australian community on Bridging Visas during June September 2013. Several hundred more in the legacy caseload remained in detention or were returned to detention after cancellation of their BV.

The ability to work while on a BV was re-instated in December 2014. Those unable to work while living in the community have limited financial and case management support through the government funded Status Resolution Support Service (SRSS) ${ }^{2}$.

Studies on the legacy caseload by non-government organisations and academics indicate that these people are suffering from a number stressors including: difficulties accessing employment and affordable housing, poverty and isolation. Those in the legacy caseload have been waiting for almost four years for their protection claims to be assessed. All reports identify ongoing uncertainty relating to visa status as causing significant mental distress (Fleay et al 2013; Doney 2014; Mares 2014; Australian Red Cross 2013, UNHCR 2013).

\footnotetext{
${ }^{2}$ Details about the programme can be found on the Department of Immigration and Border Protection website https://www.border.gov.au/Trav/Refu/Illegal-maritime-arrivals/status-resolution-support-services-programme$\underline{\text { srss. }}$. Different levels of assistance are provided according to certain bands. The vast majority of asylum seekers are in Band 6, which is the "lightest" form of assistance.
} 
These findings are consistent with research which links delays in the adjudication of an asylum seeker's claims, the resulting uncertainty and fear of a potentially negative outcome with psychological distress above and beyond the impact of pre-existing trauma (Human Rights First 2016). Evidence suggests that seeking asylum is both directly and indirectly a stressful and disturbing experience and, in some instances, closely related to suicide and selfharm (Procter 2008). Ongoing mental decline and acute distress could be factors in at least three suicides among asylum seekers living in the community over the last few years. ${ }^{3}$ This is clearly illustrated in this quote from a friend of Leo Seemanpillai, a Tamil asylum seeker who took his own life in 2014.

"He went through so much in his life, and when he came to Australia he was given a visa that is filled with plenty of uncertainty, he couldn't accept that,” Annan said through a translator.

"Leo would always talk about his visa status ... He would always worry about what would happen to him.”

Annan spoke of the fear many of Seemanpillai's friends shared of being sent back to Sri Lanka. "It is always in our mind," he said. (Laughland 2014).

In Australia, studies comparing the mental health of asylum seekers who received permanent protection visas with asylum seekers who had been found to be refugees and received temporary protection visas (TPV) demonstrated that holders of TPVs were more likely to have clinically recognisable psychiatric conditions. The research postulated this could be due to a continuing range of events and experiences, including the experiences of detention prior to being released on a TPV but was also related to the uncertainty of their future visa status (Momartin et al 2006; Procter 2005).

\section{A new system of refugee status determination and the re-introduction of temporary protection}

Further compounding the mental health and social challenges of the legacy caseload is the complexity of the refugee status determination process in Australia. These procedures have

\footnotetext{
${ }^{3}$ October 2015 an Afghan, Khodayar Amini, set himself on fire while on a video call with two refugee advocates. He said he feared being detained again. June 2015, Raza, Afghan Hazara, jumped in front of a Perth train. He was living on a bridging visa and had been interviewed by police a day earlier. In October 2014, a 29year-old Tamil, Leo Seemanpillai, set himself on fire outside his house. He suffered burns to $90 \%$ of his body and died in hospital. Details from the Australian Border Deaths Database http://artsonline.monash.edu.au/thebordercrossingobservatory/publications/australian-border-deaths-database/.
} 
become more difficult due to a raft of recent legal and procedural changes. In December 2014 laws were passed ${ }^{4}$ introducing Temporary Protection Visas (TPVs) and Safe Haven Enterprise Visas (SHEVs) for those who arrived in Australia by boat without a visa. ${ }^{5}$ The laws also introduced a new system to process protection claims made by the legacy caseload. The Fast Track Assessment (FTA) procedure will allow asylum seekers to make an application for protection to the Department of Immigration and Border Protection ('Department of Immigration'). Applications that are refused will be referred to a newly created Independent Assessment Authority (IAA). Reviews by the IAA will be conducted “on the papers”. ${ }^{6}$ Only in 'exceptional circumstances' will the IAA accept or request new information or interview the applicant. ${ }^{7}$ In some cases an asylum seeker will have no access to independent review. This can occur in circumstances including where the Department of Immigration assesses the asylum seeker's case to be "manifestly unfounded” or where the Department of Immigration finds that the asylum seeker has effective protection in another country or where the asylum seeker has produced a "bogus document" without reasonable explanation. ${ }^{8}$ When the laws were introduced several legal and human rights organisations were concerned that the system of limited review would arbitrarily and unfairly exclude procedural fairness from the protection visa process (Law Council of Australia 2014b; Australian Human Rights Commission 2014, Refugee Council of Australia 2014).

The combined effect of these new provisions places increased pressure to ensure that the initial application is one which is as thorough and complete as possible. Credibility assessment has always been a major issue in refugee determinations and its importance increases in the context of this FTA processes which has severely curtailed merits review and in some cases removed it altogether (Kenny \& Procter 2015). As refugee determinations become less reviewable, it is increasingly important to get the application right the first time (Millbank 2009). This is also stressed in information provided by the Department of Immigration to asylum seekers.

\footnotetext{
${ }^{4}$ These changes were contained in the Maritime Powers Legislation Amendment (Resolving the Asylum Legacy Caseload) Act 2014 (Cwth).

${ }^{5}$ These are visas available to asylum seekers who arrive in Australia without a valid visa by boat or by plane where it has been found that they are owed protection. The TPV is a three year visa. The SHEV is a five year visa. The SHEV allows for a person who has studied or worked in a regional area for 3.5 years to apply for certain work, study or family visas at the end of the visa.

${ }^{6}$ According to the Migration Act 1958 (Cwth) the IAA will generally decide a case on the basis of written information already provided and will generally not hold a hearing or interview with the applicant - Migration Act 1958 s 473DB,

${ }^{7}$ Migration Act 1958 (Cwth) s 473 DD.

8 These are known as ‘excluded fast track applicants’ Migration Act 1958 (Cwth) s 5(1).
} 
Under the Fast Track Assessment Process, it is extremely important to give us your protection claims early and in full. If you do not give us all of your protection claims and we refuse your application, you might not have another chance to provide these claims. [emphasis in the original text] (DIBP 2016b)

The processes commences when an asylum seeker is invited to apply for either a TPV or a SHEV. ${ }^{9}$ They are given 60 days from the date of the letter to submit their application and supporting evidence. The application form must be completed in English and they are required to provide extensive details about their identity, family (here and overseas), education, residences, travel history, employment and explain how they meet the definition of a refugee. ${ }^{10}$ The forms must be accompanied with evidence of their identity or a "reasonable explanation" as to why identity documents are not available. ${ }^{11}$ They will then attend an interview where an officer from the Department of Immigration will question them further about their identity and claims.

There are a variety of factors that make it difficult for an asylum seeker to present a comprehensive account of their claims, including: literacy, language, culture, a lack understanding of the RSD system and the complexities of that system; limited access to legal representation and difficulty with memory recall and in telling painful and often traumatic experiences (Hunter et al 2013). Interviews conducted with asylum seekers trying to navigate the legal system show they find the legal process to be confusing, inconsistent and demeaning (Australian Red Cross 2013; Commonwealth of Australia 2012, UNHCR 2013).

\begin{abstract}
You have your rights and everyone is...the same, everyone is equal, but they [Immigration] don't deal with you....they deal with you as a number...do not look at citizenship just look at them as humans. They [Immigration] don't deal with you. They deal with you as a number in a file....They broke me, they destroyed me, they just turned me to dust....everything is broken... when something is broken, you can’t fix it. (interview January 8, 2012). (Australian Red Cross 2013, 64)
\end{abstract}

\footnotetext{
${ }^{9}$ Under the Migration Act 1958 (Cwth) unauthorised maritime arrivals are barred from lodging any visa application (s 46A(1)). The Minister for Immigration personally can allow for a person to lodge a visa of a specified class s 46A(2). This is known as 'lifting the bar'.

${ }^{10}$ Form 790 (Application for a Safe Haven Enterprise Visa) or Form 866 (Application for a Protection Visa).

${ }^{11}$ Section 91W of the Migration Act 1958 (Cwth) provides that the Department of Immigration may request a protection visa applicant to provide documentary evidence of their identity, nationality or citizenship. The section authorises the Department of Immigration to refuse the visa if the visa applicant fails to produce such documents or provides a bogus document, unless they have a reasonable explanation for not having them and have taken reasonable steps to obtain them.
} 
Every day there is a new law whether it has been passed or hasn't there are all rumours around...there is the news regarding the temporary visa you can hear it on TV. Sometimes we are told we are going to have work permit, sometimes they say no work permit. Make a decision and tell us what it is, so we know where we stand. Every day we hear the rumours and it is very distressing. [asylum-seeker] (UNHCR 2013, 14)

Processing of the legacy caseload began in late 2015. Currently, the Department of Immigration has invited more than 12,000 individuals in the legacy caseload to lodge claims via the FTA process (Robinson 2016). The Department estimates it will take at least three years to get through primary processing. The upcoming processing of their cases is likely to be a trigger for further stress and distress. Refugee status determination processes and social factors including uncertainty regarding status leading up to the process are closely associated with symptoms of post-traumatic stress disorder and major depressive disorders (Kenny \& Procter 2014). Processing is likely to be protracted and rejections of some asylum claims are likely. Research has found that rejections of asylum claims contribute directly to PTSD (Hocking, Kennedy \& Sundram 2015).

For those asylum seekers who manage to navigate the new FTA process successfully, they will only be granted temporary protection for a further three years (TPV) or five years (SHEV). Judith Herman, in what is considered to be the seminal text on PTSD, outlined a three stage recovery process, the first of which was 'establishing safety' (1997). The TPV or SHEV, because of their temporary nature precludes the capacity to establish safety (Fiske \& Kenny 2004).

While on a TPV or a SHEV refugees are able to work, access Medicare and Centrelink. However they are not able to leave and return to Australia nor will they be able to sponsor any family members to Australia. The ongoing temporary nature of their residence status and ongoing separation from family is likely to add to deepening mental deterioration. This is illustrated by this interaction between a lawyer and his client who he describes as being “crushed” by Australian immigration laws.

Having explained [the legal process] to Hamid, I thought he was about to cry. Maybe he did after he left the office. I can understand why. He is now unable to see a way of reuniting with his family in the short term, or getting a long term solution for himself and his family (Murphy 2015). 


\section{Funded legal assistance: the Primary Application and Information Service (PAIS)}

In March 2014 the Abbott Coalition government announced the removal of funding for legal assistance for asylum seekers arriving by boat. Previously all boat arrivals had access to funded assistance through the Immigration Application Advice and Assistance Service (IAAAS). It was claimed the withdrawal of IAAAS for unauthorised maritime arrivals would save \$100 million from the budget (Morrison 2014).

The withdrawal of taxpayer funded immigration advice and assistance does not prevent those who arrived illegally having access to legal assistance. In addition, those who wish to provide immigration advice and application assistance pro bono are free to do so.

Access to any private and/or pro bono immigration advice by illegal boat or air arrivals will be facilitated by the Department of Immigration and Border Protection, with all costs to be met by the providers of these services.

If people choose to violate how Australia chooses to run our refugee and humanitarian programme, they should not presume upon the support and assistance that is provided to those who seek to come the right way, and they should certainly not receive additional assistance, as they did under the previous government.

Under these changes the government will provide illegal arrivals clear instructions in multiple languages setting out the asylum application and assessment process and will provide interpreters. This is similar to the process employed by the UNHCR around the world. (Morrison 2014).

The Minister also announced that some support would be provided by way of the Protection Application Information Service (PAIS) for those considered "extremely vulnerable” and unaccompanied minors (Morrison 2014). Current government policy is that PAIS is only available to a small percentage of protection visa applicants and the budget for this programme reflects this position. The budget for PAIS is $\$ 4.8$ million per annum for each financial year from 2014/15-2016/17 (Commonwealth of Australia 2015, p. 54). This represents about \$2000-3000 per client (depending on whether it is an individual or family) (Commonwealth of Australia 2015, p. 54). In theory this would amount to approximately 1520 per cent of the legacy caseload.

\section{Vulnerability Assessment and Eligibility for PAIS}

The eligibility criteria for PAIS are set out in the Department of Immigration Procedures Advice Manual (PAM3) (DIBP 2016a). Assessments for PAIS are made by the Department of Immigration and there is no formal application process. Eligibility is based upon an 
individual being assessed to be "exceptionally vulnerable", in the sense that the individual would lack the capacity or ability to understand and engage adequately in the protection assessment process without assistance. How vulnerability is considered in the PAIS context is discussed below.

"Vulnerability" is a term that has arisen recently in legislation and jurisprudence and it is a term that is frequently used with respect to asylum seekers. While the term is widely used, it is clear that there is no common or accepted definition of vulnerability. What is most striking is the range of applications within the asylum seeker context. The European Court of Human Rights in M.S.S. $v$ Belgium and Greece stated that asylum seekers as a group were ‘particularly underprivileged and vulnerable ... and in need of special protection' (p 251). In other legal contexts vulnerability is used to identify asylum seekers with special needs that may require a higher level of protection (Petin 2016). For example the UNHCR uses a Vulnerability Assessment Framework for identifying and prioritising those most in need in humanitarian emergencies, such as in the Syrian refugee crisis (UNHCR 2014). In the United Kingdom those considered to be "vulnerable" are excluded from their detained fast track process. The Australian Migration and Refugee Division of the Administrative Appeals Tribunal have specific guidelines for how they conduct a hearing with "vulnerable persons" (AAT 2015). It is noteworthy that individual vulnerability is likely to be also situational and contextual and it is not necessarily a static concept. The situations faced by asylum seekers and how they cope may vary over time; there may be multiple and complex sets of causes ranging from economic disempowerment to social attitudes and physical limitations (Peroni \& Timmer 2013).

There is a range of vulnerability assessment tools which examine both internal and external risks and protective factors. In the Australian immigration context the Department of Immigration’s Community Status Resolution Officers use the Vulnerability Identification Assessment Tool (VIAT) to identify people who may need a higher level or oversight of support from their case managers in order to assist that person to a resolution of their immigration status. ${ }^{12}$ While not diagnostic in nature, the VIAT is known largely as a decision support tool designed to assist case managers to identify and describe the nature of individual

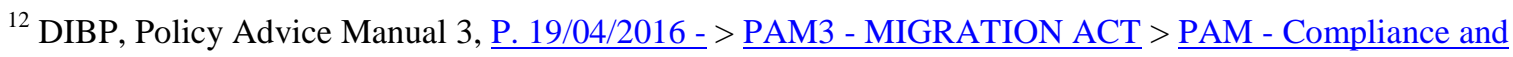
Case Resolution > Case resolution > Community Status Resolution Service.
} 
vulnerability, the presence of additional risk factors for worsening vulnerability, and other factors that may be broadly deemed protective or supportive of the individual.

\section{Assessing PAIS eligibility}

Initial assessments for PAIS are performed 'using information on the departmental system' (DIBP 2016a) which might be information the Department of Immigration has gathered itself or information placed on the system by the SRSS provider. The difficulty is that these systems are not necessarily set up to gather standardised information and thus assessments of vulnerability are made by individual Department officers in the absence of a standardised assessment tool, such as the VIAT.

Policy guidance ${ }^{13}$ is provided to officers assessing whether a person qualifies for PAIS, the key factor being whether the individual has a 'functional impairment' which impacts upon their 'ability to engage in the protection process'. The guidelines state that an officer 'must take account of all of the available information in relation to an individual's circumstances, including the cumulative effect of these circumstances where the individual has a number of conditions affecting their capacity to understand and articulate their claims. ${ }^{, 14}$

The policy details particular conditions that should be considered including intellectual disabilities, brain injuries and incapacitating illnesses. Asylum seekers will only be eligible for assistance on mental health grounds if they have a "serious mental illness" such as schizophrenia, severe depression or post-traumatic stress disorder. It states that "less serious mental illness” such as “anxiety or less severe depression” will not normally impact upon a person's ability to engage in the protection process. This policy analysis is problematic; people diagnosed with depression (for example) often experience difficulties in thought, feeling and emotion. Changes in emotion may impact upon concentration and decision making. Such symptoms form part of the assessment criteria for major depression, thus recognising that cognitive impairment is a core feature associated to this condition (Sole et al. 2015). Difficulties in thought and feeling, as well as indecisiveness may persist in vulnerable individuals even when depressive symptoms have subsided or resolved (McIntyre 2013).

\footnotetext{
${ }^{13}$ DIBP, Assessing PAIS Eligibility 19/04/2016 - > P. 19/04/2016 - > PAM3 - REFUGEE AND HUMANITARIAN > PAM - Protection visas - Temporary Protection and Fast Track Assessment Process.

${ }^{14}$ DIBP, Assessing PAIS Eligibility 19/04/2016 - > P. 19/04/2016 - > PAM3 - REFUGEE AND HUMANITARIAN > PAM - Protection visas - Temporary Protection and Fast Track Assessment Process.
} 
These cognitive problems compromise an individual's coping abilities and in turn the inhibit them articulating their protection claims and understanding the RSD process.

The current emphasis on limited medical diagnostic criteria is problematic and limiting. Understanding idioms of mental distress and its accurate reporting for people of diverse cultural and linguistic backgrounds has been the subject of misunderstanding, neglect and exclusion from clinical practice and reporting processes within mental health and mainstream health services (Minas et al. 2013). The central concern is that inaccurate diagnosis is aligned with persistent disparities in availability of and access to mental health services, quality of care and mental health outcomes for people from immigrant and refugee backgrounds.

As outlined above there are many asylum seekers in the legacy caseload that may be in a desperate emotional state whether or not they meet the classification of formal psychiatric disorder. Diagnosis of mental illness is not a straightforward practice for people of culturally and linguistically diverse (CALD) background. There are many additional barriers such as language and access to interpreters, stigma and fear based reluctance to seek mental health support, lack of culturally competent mainstream service providers and limited access to specialist psychiatric assessment. There is likely to be untreated symptoms of mental despair as well as mental illness, for example cognitive decline, symptoms and other expressions of mental distress in this population. The PAIS policy criteria also fails to include a series of other factors which are significant indicators of vulnerability such as age, gender, sexual orientation, family violence, homelessness, destitution and substance abuse issues.

The factors described above support the proposition that the current assessment process for determining “exceptional vulnerability” has a number of flaws. However it should be acknowledged that those working in the Department of Immigration have a very difficult task to determine how extremely limited funding can be allocated to 15 or 20 per cent of the legacy cohort.

The reality is under current government policy the majority of asylum seekers will be excluded from this funding assistance. According to the government asylum seekers can have legal representation at their own expense; the problem is any right to representation becomes illusory if the asylum seeker cannot afford to pay. The challenge will be processing the 75-80 per cent who will not receive PAIS. Pro bono assistance is offered across the country through 
community legal centres and not-for-profit organisations; however they are struggling to meet the demand upon their services, especially when this reduction to funding is combined with cuts made nationally to the budgets of legal aid and community legal centres.

\section{Legal assistance and fair refugee status determination}

In referring to the withdrawal of funded legal assistance the Minister for Immigration and Border Protection said 'Australia's protection obligations do not extend to providing free immigration advice and assistance to those who arrived in Australia illegally’ (Morrison 2014). A recent interaction between an officer of the Department of Immigration and Labour Senator, Kim Carr, during a hearing in the Australian Senate indicated that previous funding was perhaps a sign of Australia's largesse rather than as a reflection of any legal obligation.

Mr Kukoc: Previously [legal] assistance was provided to all illegal maritime arrivals, which was quite unique, because no other country in the world provides free-of-charge immigration assistance to refugee protection claims.

Senator KIM CARR: It may well be unique, but it was a hallmark of the way in which we treated people. (Commonwealth of Australia 2015, p. 46)

An examination of our international protection obligations and Australian domestic law in relation to a requirement to accord procedural fairness toward asylum seekers in fact indicates that Australia may well have an obligation to provide access to funded legal assistance.

Australia's international protection obligations are found in the Convention relating to the Status of Refugees (Refugees Convention) and other human rights treaties. Under these international treaties Australia has agreed to abide by the principle of non-refoulement which means that Australia must not return a person to a country where they would face persecution, torture or other cruel, inhumane and degrading treatment. The Refugees Convention does not prescribe procedures to be adopted by countries in the processing of protection claims. The key international agency overseeing the Refugees Convention, the United Nations High Commissioner for Refugees (UNHCR), recognises that it is for each country to establish the most appropriate procedures for processing claims, including review mechanisms, although it recommends that there should be certain minimum requirements (UNHCR 2005). The right to legal assistance is seen by UNHCR as an 'essential safeguard' and that it is important that countries guarantee 'free legal assistance and representation in first instance procedures and 
against negative decisions’ particularly for vulnerable groups (UNHCR 2005, p. 3). The European Council of Refugees in Exile also recommends that legal aid should be made available to asylum seekers who lack resources (ECRE 2010).

In Australia there is no guaranteed right to funded legal assistance. However the High Court has stated that in serious criminal matters the lack of legal representation can lead to procedural unfairness. In Dietrich v The Queen Mason CJ and McHugh J said:

Australian law does not recognize that an indigent accused on trial for a serious criminal offence has a right to the provision of counsel at public expense. Instead, Australian law acknowledges that an accused has the right to a fair trial and that, depending on all the circumstances of the particular case, lack of representation may mean that an accused is unable to receive, or did not receive, a fair trial.

(Dietrich $v$ The Queen (1992) 177 CLR 292, 317)

While this case referred to people on criminal charges, procedural fairness in the context of the processing of refugee status is regarded seriously by the Australian courts, particularly given the gravity of the consequences for those affected by the relevant decision (Crock \& Martin 2013). According to a number of studies conducted in other jurisdictions, a lack of representation has a major impact upon the fairness of the refugee status determination procedures. One prominent study in the US found that represented asylum seekers were granted asylum at a rate of 45.6 per cent before the Immigration Courts whereas unrepresented asylum seekers were granted asylum at a rate of 16.3 per cent (Ramji-Nogales et al. 2007). An extensive study of more than seventy thousand decisions made by the Canadian Refugee Protection Division from 2005 to 2009 concluded that representation by legal counsel was a critical factor for successful refugee claims (Rehaag 2011).

The government has argued the policy of reducing funding for legal assistance will lead to significant budget savings. The Law Council of Australia has pointed out that it may have the reverse effect in that having more unrepresented applicants will increase inefficiencies for the Department of Immigration in finalising claims. Decision makers are likely to be faced with incomplete applications and deficient evidence. This will lead to an increase in the time they need to take to process and finalise the cases (Law Council of Australia 2014a). Rejection of claims where the processing was flawed or procedurally unfair may lead to the denial of meritorious asylum claims which will lead to applications for judicial review and associated costs or, at worst, the return of an individual to persecution. 
The decision to significantly reduce funding to assist a group who have been waiting for over four years for the processing of their claims runs contrary to recent developments in the United Kingdom and Ireland where governments have been piloting schemes providing early legal assistance to asylum seekers (Lane et al 2013; Anderson and Conlon 2015). Research into these schemes has demonstrated benefits for both asylum seekers and decision makers, as the provision of legal support and assistance to asylum seekers increases confidence in the process and leads to an improvement in the quality of decisions (Anderson and Conlon 2015).

\section{An integrated legal and mental health approach}

What then would be the ideal model of providing legal support and assistance to asylum seekers from the legacy caseload? A return to government funded legal assistance to all of the legacy caseload who cannot otherwise afford to pay for a migration agent or a lawyer would be an important start. Such funding needs to be adequate to allow for migration agents to prepare protection applications thoroughly. Funding levels currently must be sufficient given the complexity of the task. Low quality or incompetent assistance is linked to poor decision making (Anagnost 2000).

It has been noted previously that the administration of a system of providing legal assistance by the Department of Immigration may cause an actual if not perceived conflict of interest (Taylor 2000). Legal assistance should be provided through the Attorney General's Department via the current system of funding through a national system of legal aid which also provides funds to community legal centres.

For the reasons outlined above it is critical that the government also allow for the provision of adequate mental health support throughout the FTA process. The therapeutic merits of an integrated mental health and legal approach have been receiving greater attention in the literature (Hunter et al 2013, Procter 2008, Kenny \& Fiske 2004).

The legacy caseload are presenting as a group which is experiencing pre-existing and ongoing deterioration in their mental health. They require counseling and support from mental health professionals in order to effectively present their claims. It will also be critical for mental health support to be available at critical points of the decision making process. 
Rejection of asylum claims may be a tipping point ultimately acting as a trigger towards a trauma response. The unfortunate paradox embedded in this situation is that acceptance as a refugee may also worsen a person's perception of their situation as their residence status continues to be temporary and their future uncertain. The consequences for some individuals may be a worsening limbo and deepening uncertainty.

\section{Conclusion}

The recent changes to refugee status processing combined with a reduction in funding for legal assistance mean asylum seekers in the legacy caseload are facing an unimaginably complex process with limited support leading to deleterious effects on their mental health.

It is the role of a legal representative to adequately explain the process in a way asylum seekers can understand. Legal advice and assistance can aid the decision making process by ensuring forms are completed and the experiences of asylum seekers are documented clearly. The new FTA process will present procedural and legal challenges not experienced before in the Australian refugee determination system. In the context of a caseload of clients who are in a state of deteriorating mental decline, the role of legal assistance is particularly important.

It is difficult to disentangle the nexus between legal and mental health related concerns for asylum seekers. Current Australian law does not guarantee asylum seekers the help of a migration agent or a lawyer. This fact alone presents a serious access barrier to justice given the complexities of the Australian refugee status determination system. However, as outlined above, arguments that access to legal assistance is part of ensuring procedural fairness can be used to counterbalance that approach.

Mentally unwell and vulnerable detainees would likely benefit from an integrated legal and mental health response. The net effect would be a process that asylum seekers can place trust in, supported by professionals who they understand as prepared to advocate for their situation. Legal assistance helps asylum seekers to participate and engage in a difficult process. Mental health reactions by asylum seekers are inextricably linked to the stress of negotiating complex legal processes without structured legal assistance. While the legislative and policy changes present new and complex barriers to those in the legacy caseload, they also by 
implication bring disruption to the social and community life of those in most need of assistance.

\section{References}

Anagnost, S. 2000, 'The challenge of providing high quality, low cost legal aid for asylum seekers and refugees', International Journal of Refugee Law, vol. 12, no. 4, pp. 577588. doi: http://dx.doi.org/10.1093/ijrl/12.4.577

Anderson, B. \& Conlan, S. 2014, Providing Protection - Access to early legal advice for asylum seekers. Report prepared for Irish Refugee Council.

Ardalan, S. 2015, 'Access to justice for asylum seekers: Developing an effective model of holistic asylum representation', University of Michigan Journal of Law Reform, vol. 48, no. 4, pp. 1001-1038.

Administrative Review Tribunal 2015, Migration and Refugee Division Guidelines on Vulnerable Persons viewed 11 May 2016 http://www.aat.gov.au/AAT/media/AAT/Files/MRD\%20documents/Legislation\%20Pol icies\%20Guidelines/Guidelines-on-Vulnerable-Persons.pdf

Australian Human Rights Commission 2014, Migration and Maritime Powers Legislation Amendment (Resolving the Asylum Legacy Caseload) Bill 2014 Submission 163 viewed 11 May 2016 http://www.aph.gov.au/Parliamentary_Business/Committees/Senate/Legal_and_Constit utional_Affairs/Asylum_Legacy_Caseload_Bill_2014/Submissions

Australian Red Cross 2013, Inaugural Vulnerability Report: Inside the process of seeking asylum in Australia, June, Australian Red Cross, viewed 11 May 2016 http://www.redcross.org.au/files/ARC_VulnerabilityReport_LR.PDF

Commonwealth of Australia 2012, The Management of Enforced Removals in Australia: A Client Perspective, Prepared by Hall and Partners Open Mind. Department of Immigration and Citizenship, Commonwealth of Australia.

Commonwealth of Australia 2015, Senate Legal and Constitutional Committee, Estimates, Immigration and Border Protection Portfolio, 26 May 2015.

Crock, M. \& Martin, H. 2013, 'Refugee rights and the merits of appeals', University of Queensland Law Journal, vol. 32, no. 1, pp. 137-155.

Department of Immigration and Border Protection (DIBP) 2016a Procedures Advice Manual (PAM 3).

DIBP 2016b, 'Applying for protection in Australia if you arrived illegally' viewed 11 May 2016. https://www.border.gov.au/Trav/Refu/protection-application-information-andguides-paig/applying-for-protection-in-Australia-if-you-arrived-illegally

Doherty, B. \& Hekmat, A. 2016, “"We are the forgotten people”: the anguish of Australia's “invisible” asylum seekers', The Guardian Australia, 13 April, viewed 11 May 2016, http://www.theguardian.com/australia-news/2016/apr/13/we-are-the-forgotten-peoplethe-anguish-of-australias-invisible-asylum-seekers.

Doney, D. 2014, A welcome home: An evaluation of AMES' accommodation services for refugees and asylum seekers, Centre for Refugee Research UNSW, viewed 11 May 2016. https://www.ames.net.au/files/file/Settlement/AMES_UNSW.pdf

European Council on Refugees and Exiles (ECRE) 2010, Survey on legal aid for asylum seekers in Europe, viewed 11 May 2016 http://www.ecre.org/component/downloads/downloads/268.html 
Fleay, C., Hartley, L. \& Kenny, M. 2013, 'Refugees and asylum seekers living in the Australian community: The importance of work rights and employment support', Australian Journal of Social Issues, vol. 48, no. 4, pp. 473 - 493.

Gruhn, R. 2014 “Can you please help me? How can we live?” Uniting Care's emergency relief and crisis support for asylum seekers living in the community, March. Report prepared for Uniting Care Victoria and Tasmania, viewed 11 May 2016 http://apo.org.au/files/Resource/unitingcare_unitingcaresemergencyreliefandcrisissuppo rtforasylumseekerslivinginthecommunity_mar_2014.pdf

Herman, J. 1997, Trauma and Recovery. The Aftermath of Violence - from Domestic Abuse to Political Terror, Basic Books, New York.

Hocking, D., Kennedy, G. \& Sundram, S. 2015, 'Mental disorders in asylum seekers: the role of the refugee determination process and employment', The Journal of Nervous and Mental Disease, vol. 203, no. 1, pp. 28-32. doi: http://dx.doi.org/10.1097/NMD.0000000000000230

Human Rights First 2016, In the Balance: Backlogs Delay Protection in the U.S. Asylum and Immigration Court Systems, April 2016, viewed 11 May 2016 http://www.humanrightsfirst.org/sites/default/files/HRF-In-The-Balance.pdf

Hunter, J., Pearson, L., San Roque, M. \& Steel, Z. 2013, 'Asylum adjudication, mental health and credibility evaluation', Federal Law Review, vol. 41, no 3, pp. 471-495.

Kenny, M. \& Procter N. 2015, 'The fast track refugee assessment process and the mental health of asylum seekers', Psychiatry, Psychology and the Law, vol. 23, no. 1, pp. 6268. doi: http://dx.doi.org/10.1080/13218719.2015.1032951

Kenny, M. \& Fiske, L. 2004, '"Marriage of Convenience" or a "Match Made in Heaven": Lawyers and social workers working with asylum seekers', Australian Journal of Human Rights, vol. 10, no. 1, pp. 137-157.

Lane, M., Murray, D., Lakshman, R., Devine, C. \& Zurawan, A. 2013, Evaluation of the Early Legal Advice Project: Final Report, Report for the UK Home Office, May 2013, viewed 11 May 2016 https://www.gov.uk/government/uploads/system/uploads/attachment_data/file/199962/ horr70.pdf

Law Council of Australia 2014a, Law Council concerned by the removal of IAAAS funding. Media Release 2 April 2014, viewed on 11 May 2016 https://www.lawcouncil.asn.au/lawcouncil/images/LCA-PDF/mediaReleases/1409_-_Law_Council_concerned_by_removal_of_IAAAS_Funding.pdf

Law Council of Australia 2014b, Migration and Maritime Powers Legislation Amendment (Resolving the Asylum Legacy Caseload) Bill 2014 Submission 129 viewed 11 May 2016 http://www.aph.gov.au/Parliamentary_Business/Committees/Senate/Legal_and_Constit utional_Affairs/Asylum_Legacy_Caseload_Bill_2014/Submissions

Laughland, O. 2014, 'Tamil asylum seeker's grieving family unable to attend funeral', The Guardian Australia, 16 June, viewed 11 May 2016, http://www.theguardian.com/world/2014/jun/16/tamil-asylum-family-unable-attendfuneral

Mares, P. 2014, 'Refuge without work', Griffith Review, vol. 45, viewed 11 May 2016 https://griffithreview.com/articles/refuge-without-work/

McIntyre, R. 2013, 'Using measurements strategies to identify and monitor residual symptoms', Journal of Clinical Psychiatry, vol. 74, no. 2, pp. 14-18. doi: http://dx.doi.org/10.4088/JCP.12084su1c.03 
Millbank, J. 2009, “"The Ring of Truth”: A case study of credibility assessment in particular social group refugee determinations,' International Journal of Refugee Law, vol. 21, no. 1, pp. 1-33. doi: http://dx.doi.org/10.1093/ijrl/een040

Minas, H., Kakuma, R., Too, L., Vayani, H., Orapeleng, S., Prasad-Ildes, R., Turner, G., Procter, N.G., Oehm, D. 2013, 'Mental health research and evaluation in multicultural Australia: Developing a culture of inclusion', International Journal of Mental Health Systems, vol. 7, pp. 1-25. doi: http://dx.doi.org/10.1186/1752-4458-7-23

Momartin, S., Steel, Z., Coello, M. \& Aroche, J. 2006, 'A comparison of the mental health of refugees with temporary versus permanent protection visas', Medical Journal of Australia, vol. 185, no. 7, pp. 357-361.

Morrison, S. 2014, 'End of taxpayer funded immigration advice to illegal boat arrivals saves \$100 million', Minister for Immigration and Border Protection Media Release, 31 March 2014.

Murphy, K. 2015, 'Hamid crushed by Australia's immigration laws’ Eureka Street vol. 27, no. 19, viewed 11 May 2016 http://www.eurekastreet.com.au/article.aspx?aeid=45485\#.Vy6tgXlJmUn

Peroni, L. \& Timmer, A. 2013, 'Vulnerable groups: The promise of an emerging concept in European Human Rights Convention law', International Journal of Constitutional Law, vol. 11, no. 4, pp. 1056-1085. doi: http://doi.dx.org/10.1093/icon/mot042

Phillips, J. 2014, Boat arrivals in Australia: a quick guide to the statistics. Parliament of Australia viewed 11 May 2016 http://www.aph.gov.au/About_Parliament/Parliamentary_Departments/Parliamentary_ Library/pubs/rp/rp1314/QG/BoatArrivals

Procter, N.G., 2005, “"They first killed his heart (then) he took his own life”. Part 1: A review of the context and literature on mental health issues for refugees and asylum seekers', International Journal of Nursing Practice, vol. 11 no. 6, pp.286-291. doi: http://dx.doi.org/10.1111/j.1440-172X.2005.00537.x

Ramji-Nogales, J., Schoenholtz, A. \& Schrag, P. 2007, 'Refugee roulette: Disparities in asylum adjudication’, Stanford Law Review, vol. 60, no. 2, pp. 295-411.

Refugee Council of Australia 2014, Migration and Maritime Powers Legislation Amendment (Resolving the Asylum Legacy Caseload) Bill 2014 Submission 136, viewed 11 May 2016, http://www.aph.gov.au/Parliamentary_Business/Committees/Senate/Legal_and_Constit utional_Affairs/Asylum_Legacy_Caseload_Bill_2014/Submissions

Rehaag, S. 2011, ‘The role of counsel in Canada’s refugee determination system: An empirical assessment', Osgoode Hall Law Journal, vol. 49, no.1, pp. 71- 116.

Robiant, K., Hassam, R. \& Katona, C. 2009, 'Mental health implications of detaining asylum seekers; systematic review', British Journal of Psychiatry, vol. 194, no. 4, pp. 306-312. doi: http://dx.doi.org/10.1192/bjp.bp.108.053223

Robinson, N. 2016, 'Fast-track' process for asylum seekers to result in lengthy delays as court challenges mount', Australian Broadcasting Corporation, 16 April, viewed 11 May 2016, http://www.abc.net.au/news/2016-04-16/fast-track-process-asylum-seekerslengthy-delays-court-challenge/7331296

Sinnerbrink, I., Silove, D., Field, A., Steel, Z. \& Manicavasagar, V., 1997, 'Compounding of premigration trauma and postmigration stress in asylum seekers', The Journal of psychology, vol. 131 no. 5, pp. 463-470. doi: http://dx.doi.org/10.1080/00223989709603533

Sole, B., Jimenez, E., Martinez-Aran, A. \& Vieta, E. 2015, 'Cognition as a target in major depression: New developments', European Neuropsychopharmacology, vol, 25, no. 2, pp. 231-247. doi: http://dx.doi.org/10.1016/j.euroneuro.2014.12.004 
Smith-Khan, L., Crock, M., Saul, B. \& McCallum, R. 2015, 'To 'Promote, Protect and Ensure': Overcoming obstacles to identifying disability in forced migration', Journal of Refugee Studies, vol. 28, no. 1, pp. 36- 68. doi: http://dx.doi.org/10.1093/jrs/feu020

Taylor, S. 2000, 'Should unauthorised arrivals in australia have free access to advice and assistance?' Australian Journal of Human Rights, vol. 6, no. 1, pp. 34-58.

UN High Commissioner for Refugees (UNHCR) 2005, Fair and Efficient Asylum Procedures: A Non-Exhaustive Overview of Applicable International Standards, 2 September 2005, viewed 11 May 2016, http://www.refworld.org/docid/432ae9204.html

UNHCR 2010, The Heightened Risk Identification Tool, June 2010, $2^{\text {nd }}$ ed., viewed 11 May 2016, http://www.refworld.org/docid/4c46c6860.html

UNHCR 2005, Fair and Efficient Asylum Procedures: A Non-Exhaustive Overview of Applicable International Standards, 2 September, viewed 11 May 2016, http://www.refworld.org/docid/432ae9204.html

UNHCR 2013, Asylum-seekers on bridging visas in Australia: Protection Gaps, 16 December, viewed 11 May 2016 http://unhcr.org.au/wp-content/uploads/2015/05/201312-16-Asylum-seekers-on-bridging-visas-in-Australia-1.pdf

UNHCR 2014, Introducing the Vulnerability Assessment Framework, viewed 11 May 2016, https://data.unhcr.org/syrianrefugees/download.php?id=7877

UNHCR 2015, UNHCR Global Trends 2014: World at War, viewed 11 May 2016, http://www.refworld.org/docid/558292924.html

\section{Cases}

Dietrich v The Queen (1992) 177 CLR 292

M.S.S. v Belgium and Greece [GC], ECtHR, Application No. 30696/09

\section{Legislation}

Maritime Powers Legislation Amendment (Resolving the Asylum Legacy Caseload) Act 2014 (Cwlth)

Migration Act 1958 (Cwlth) 